\title{
Criminal Policy of Village Fund Corruption in Indonesia
}

\author{
Andriansyah Kartadinata ${ }^{1}$, Muhammad Ghifari ${ }^{2}$, Fasial Santiago ${ }^{3}$ \\ Universitas Borobudur Jakarta ${ }^{123}$ \\ \{andri86policelightstore@gmail.com ${ }^{1}$,muhammadghifari@gmail.com², \\ faisalsantiago@borobudur.ac.id $\left.{ }^{3}\right\}$
}

\begin{abstract}
The Village Fund Corruption Crime is the highest corruption crime among the cases included in the Corruption Eradication Commission (KPK) report, in 2019 there were 46 corruption cases in the village budget sector out of a total of 271 corruption cases in Indonesia. Corruption in the village budget alone has cost the state up to 32.3 billion. The objectives to be achieved from this research are related to the formulation of legal policies on criminal acts of corruption in village funds, saving village funds from corruption, and law enforcement on criminal acts of corruption in village funds. The research method used by the author is a juridical-normative approach that finds legal principles and norms in formulating criminal acts of corruption in village funds.
\end{abstract}

Keywords: author Corruption; Village Fund; Prevention

\section{Preliminary}

Village Funds became a new source of finance for villages after Law No. 6/2014 on Villages was passed. According to the law, village funds are funds sourced from the State Revenue and Expenditure Budget (APBN) which are allocated for villages that are transferred through the Regency/City Regional Revenue and Expenditure Budget (APBD). The village funds are used to finance government administration, development implementation, correctional financing, and community empowerment. To increase the effectiveness and efficiency of the use of village funds, a particular regulation was formed regarding village funds which is a derivative of Law Number 6 of 2014 concerning Villages, namely Government Regulation of the Republic of Indonesia Number 8 of 2016 concerning the Second Amendment to Government Regulation Number 60 of 2014 concerning Village Funds sourced from the State Revenue and Expenditure Budget (APBN). In the PP, there is a regulation on Village Funds that aims to create effectiveness and efficiency in the use of Village Funds by improving the distribution stages of Village Funds. The process of distributing village funds to villages must pay attention to the aspect of accountability.

In regulation, the management of village funds is expected to be able to improve the welfare of village communities, because a prosperous society will strengthen the country and have high competitiveness toward other countries. Welfare itself is a condition in which every demand for a quality life can properly be fulfilled, therefore welfare is an important value that 
must be prioritized to be realized by all Indonesian people. One of the factors of this welfare is through village funds (Winarni, 2018).

The current allocation of village funds is focused on village infrastructure development and community empowerment, but ironically in its implementation, there have been many corrupt practices in the management of village funds. Either intentional or unintentional (due to ignorance of how to use and reporting administratively) by village officials and village heads concerning the use of village funds (Marten et al, 2018).

Prevention of corruption is a government commission that is very likely to be implemented in the context of accomplishing a clean and authoritative state administration. The spirit of good governance can be realized through the application of the dimensions of accountability and budget transparency in regional government, including the budget owned by the village which comes from the APBN, namely village funds as mandated by Law Number 6 of 2014 concerning Villages.

Monitoring of corruption in the village has been conducted by ICW based on ICW's monitoring results, cases of corruption in villages in the range of 2016-2019 have increased. In 2016, there were 41 cases which then increased to 96 cases in 2017. The growth of cases still doubled in 2018 where there were 181 cases and increased again to 271 in 2019. If we count the total cases of corruption found is 589 cases.

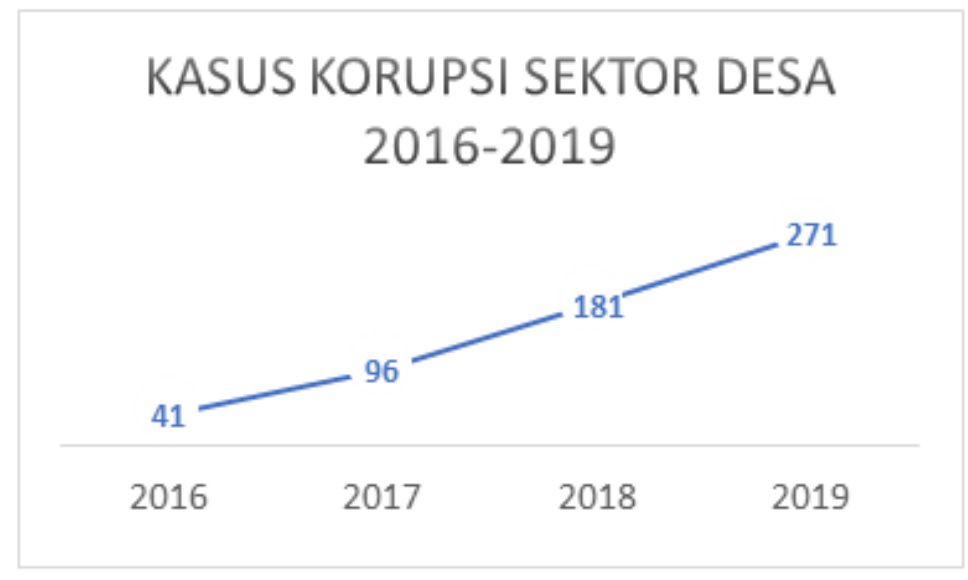

Fig. 1. Corruption Occurred in the Village

Source: ICW, 2019

589 cases of corruption occurred in the village, but not all of them were cases of corruption in the village budget. There were 127 cases related to the village budget, while 489 cases occurred in village non-budget objects if presented $18 \%$.

The author tries to map the problems that exist in the management of village funds in terms of gaps for village heads and officials to abuse their authority and village funds for things beyond those that have been programmed before. Another thing that the author caught in the weak performance of law enforcers in dealing with the problem of corruption in village funds due to the limited number of law enforcement officials, while the number of villages that must be monitored is that according to the Minister of Home Affairs Regulation Number 56 of 2015 concerning Code and Data for Government Administration Areas, it is stated that 83,184 consisting of 74,754 villages and 8,430 villages. 
Regarding the corruption of village funds, the author conducted tracing several previous studies related to village funds:

a. Wahani (2014) states that efforts to eradicate corruption in Indonesia still tend to be less effective, the contributing factor is due to the leadership's commitment to formulating anti-corruption policies, improving the quality of public services that are free from KKN, transparent and accountable financial management and the availability of financial managers who are having integrity, improving government administration; and the existence of an independent supervisory body and the availability of auditors with integrity.

b. Fikri Habibi and Arif Nugroho (2018) accountability for the management of village funds can be realized through the guidance and supervision function carried out by the Regional Government, supervision can prevent potential acts of corruption.

c. Nurharibnu Wibisono and Herri Purnomo (2017) poor management of Village Funds or a tendency to abuse Village Funds, namely the dysfunction of the role of village assistants, weak elements of guidance and supervision from the Sub-district Head, Weak elements of development and supervision by the Government and Development Security Supervision Team ), poor supervision by the BPD, weak community participation in the supervision of Village Funds, high non-budgetary costs, and inadequate human resources (SDM) of Village Fund managers and Village Heads.

\section{Research Method}

The method used in this study is a normative juridical approach to find legal principles and norms in formulating criminal acts of corruption in village funds. Although it can be categorized as sociological (empirical) legal research, this study focuses on the effort to recognize the effect of the application of positive law on people's lives, because in this study the author tries to research a comprehensive approach to perceive a complete and clear picture of the problem under study. Meanwhile, it is seen from its descriptive nature, namely research that provides a clear and detailed description of the problems the author is researching, namely the law enforcement policy on corruption in village funds.

The primary data source which is the main data obtained by researchers from respondents is obtained from Corruption Eradication Commission (KPK) and the Attorney General's Office. The secondary data is obtained from the literature that supports the subject matter discussed. Secondary data can be in the form of theses, theses, dissertations, journals, newspapers, papers, seminars, brochures, and others.

The legal materials used in this research are 1) Primary legal materials which include Law Number 6 of 2014 concerning Villages; Government Regulation of the Republic of Indonesia Number 8 of 2016 concerning Second Amendment to Government Regulation Number 60 of 2014, Law Number 31 of 1999 concerning Eradication of Corruption Crimes as Amended and supplemented by Law Number 20 of 2001 concerning Amendments to Law Number 31 of 1999 concerning the Eradication of Corruption Crime; Law Number 8 of 1981 Concerning Criminal Procedure Law; Law Number 1 of 1946 Concerning Criminal Law. 2) Secondary legal materials consisting of books, journals, and newspapers. 


\section{Discussion and Analysis}

\section{1 Regulation of Village Fund Corruption Crime Formulation Policy}

Policy settings related to village funds are at least in Law Number 6 of 2014 concerning Villages. Village funds are annually budgeted in the APBN which is then given to each village as a source of village income. This village fund policy simultaneously integrates and optimizes all existing budget allocation schemes from the government to villages.

The village fund policy itself is an embodiment of the dream agenda which serves as a guideline for the village ministry in building villages, the formulation of village fund policies is already listed in Law Number 6 of 2014 and the 2015-2019 National Medium Term Development Plan (RPJMN) and 2019-2024 RPJMN.

To realize the principles of transparency and accountability and ensure the achievement of the use of village funds, the process of distributing village funds requires several criteria that must be met first, both by the village government as users of village funds and by districts/cities. Provisions regarding the distribution of village funds are regulated in the Minister of Finance Regulation No. 50 / PMK.07 / 2017 concerning Management of Transfers to Regions and Village Funds, as amended by the Minister of Finance Regulation No. $112 /$ PMK.07 / 2017.

Villages must solemnly take concrete steps to resist corruption, in ways that include the principles of transparency and accountability. What the village needs to do is make a village development program under the predetermined flow and regulations, if during a pandemic as nowadays, it certainly requires extraordinary action but it must remain in the regulation of the use of village funds. At issue in the management of funds is the number of heads of local villagers who are afraid to deal with law enforcement officers that ultimately hinder the implementation of development despite the rules relating to the government's discretion in implementation.

Regarding the discretion, President Joko Widodo has ordered the Attorney General's Office and the National Police not to criminalize discretionary acts of government administration in the context of policies and breakthroughs based on good intentions. The President is disappointed with the low absorption of government budgets, especially local governments due to the caution and concern of regional heads in discretionary actions in budget use which have an impact on administrative violations (acts against the law) and detrimental to state finances, so far administrative violations (acts against the law) and financial losses the state is considered an element of the criminal act of corruption and is subject to criminal penalties for doing so.

In terms of criminal law, discretion is not a criminal act and the perpetrator does not get a punishment. Even the Police Law stipulates that the police can use discretion that is not rigid and limited so that it can be widely interpreted. Law Number 30 of 2014 concerning Government Administration, discretion is regulated rigidly and limited to be seen the scope and limits of discretionary users.

The regulation in the law determines the norm that discretion can be used under the provisions of statutory regulations. In cases where discretion is not under the provisions of statutory regulations, discretion is declared invalid, including the accountability of the perpetrators of discretionary acts that have an impact on state administration and finances where the perpetrator is responsible for deviant discretion only if there is an abuse of authority. 
Concerning the application of legal accountability and honesty, as a measure to anticipate abuse of office and the creation of guarantees of compliance with laws and other regulations in the use of public sources of funds, the government must review the existence of existing laws and regulations, formulate and determine legal products that can bridge as well as a reference for village government administrators in carrying out village management.

Village funds are a source of public funds that must be managed based on transparency, accountability, participation, and carried out in an orderly and disciplined budget. The existing regulations aim to become a reference and guideline in terms of village fund management which will later be transformed to the provincial and district/city governments. The principles that need to be emphasized in the management of public funds, especially village funds, include:

\section{a) Managerial Accountability}

The application of managerial accountability from the cycle of village government administration begins with planning, implementation, and administration. Meanwhile, institutional management is carried out by organizing the institutional structure that handles village funds, namely the Community Empowerment Service and Village Government (DPMPD).

Village development planning is carried out by involving the Village Consultative Body and community elements in a participatory manner to utilize and allocate village resources. So far, Development Planning Deliberations (Musrebang) has often only been used as a formality and ceremonial activity, so that development priorities do not reflect real needs. With the development planning outlined in the six-year Village Medium Term Development Plan (RPJMDes) and the one-year Village Development Work Plan (RKPDes), to strengthen rights and authority and optimize village resources to improve community welfare. The village's authority to take care of its needs and interests becomes clearer with mid-term and short-term planning. Village funds that flow must be managed in a village financial system, the Village Revenue and Expenditure Budget (APBDes).

Management of village funds starts from planning to accountable implementation. To support this, financial management is carried out using the Village Financial System (SISKEUDES) application. This application contains features ranging from planning, implementing, and administering village finances sourced from the Village Fund for the APBDes by using the offline input program. This application is expected to provide managerial convenience in recording finances under the Village Development Work Plan (RKPDes).

\section{b) Implementation of Program and Policy Accountability}

The central government needs to collaborate with the provincial and district/city governments to implement program and policy accountability. Although several district governments have made a Regent Regulation on general guidelines for village fund management, which explains the priority of using village funds in financing the field of village development and empowering village communities which are decided through village meetings as priority programs, activities, budgets, and village expenditures. Even though villages have different conditions in terms of geographic conditions and basic infrastructure needs needed by villages, it is necessary to implement accountability for these programs and policies so that the relations and functions of the district/city government with the village can 
be maintained. Villages need to make a Village Medium Term Development Plan (RPJMDes) and its elaboration in the Village Development Work Plan (RKP Desa) which contains the priority scale and needs of the village community.

\section{c) Financial Accountability}

Financial accountability aims to display budget realization following predetermined programs which of course correspond to the priority scale and the needs of the village community which were decided in the village meeting. The government annually distributes a village fund allocation of $90 \%$ evenly to each village through the district/city government, while the remaining $10 \%$ is allocated by taking into account the variables of population size, poverty rate, area volume, and level of geographic difficulty. The range of village funds that were disbursed also varied, ranging from Rp. 600 million to Rp. 700 million.

Village governments that have received and used village funds are obliged to report the accountability and realization of the implementation of village funds to the local government. Supervision of village funds is carried out by the regional assistant Inspectorate as the person in charge and other stakeholders including the regent, head of the district, DPMPD, and all government in the village.

\section{d) Supervision Aspect}

Supervision of village funds is carried out internally and externally. Internal supervision is carried out by the regent, sub-district head, regional inspectorate, Community Empowerment Service, and Village Government, assistants recruited by the Ministry of Villages. Meanwhile, external supervision is carried out by the Prosecutor's Office in the Development Accelerated Development Assistance Team (TP4). This aspect is important so that the realization of the management of village funds can be realized as the original aim was to improve the welfare of the village community and increase the standard of living of the village community which is more dignified.

\subsection{Rescuing Village Funds from Corruption Crimes}

Corruption has been the biggest obstacle in governance in Indonesia. The KPK as an institution that is mandated by the government to undertake corruption matters, has carried out various initiatives to combat criminal acts of corruption in Indonesia. Various types of corruption cases carried out by several individuals with educational backgrounds and positions provide valuable lessons for all levels of society and policymakers. Meanwhile, the people who are the objects that must be made for the welfare of the state are trapped in a cycle of poverty and adversity as a result of rampant corruption. The damage and impact aspect caused by corruption can be felt in people's lives, especially when the object being corrupted is a project that has direct contact with the poor, such as social assistance. Not to mention that there are many corruption cases involving public officials from the Minister, governors, regents/mayors, and even village heads.

Corrupt behavior is also a threat to village officials in village administration, from absentee land management to village fund management corruption which is increasingly emerging in cases of trending on the topic of corruption during 2019. Referring to Indonesian Corruption Watch data, there are 46 corruption cases in the sector. village budget from a total of 271 corruption cases in Indonesia. Corruption in the village budget alone has cost the state up to 
32.3 billion. With the many cases of corruption in village funds, it shows that there is no comprehensive system that is carried out and established by the government regarding the supervision of village funds. The government needs to assist village heads and officials so that they can manage village budgets by strengthening the capacity of village residents to oversee village funds managed by village officials. With the openness and accountability of village finances coupled with the use of information technology, the management of village funds can be monitored online by both villagers and the government.

Corruption cases that occur in the village government mainly occur in terms of authority, budget, corruption of assets, and corruption abuse in the procurement of goods and services of the village government. Referring to KPK data, there are at least 14 potential problems with village funds consisting of four, namely aspects of regulation and institutions, governance, supervision, and human resources. From this aspect, it can affect the occurrence of corruption in the village government.

The implementation of the Village Law is a topic that is widely discussed by various groups related to village financial management, including the management of village resources. The management of village funds regulated in the Village Law drives the readiness of the village head in its implementation. Various reasons and factors were conveyed by the community related to the readiness of the village head and village officials, village infrastructure, and the leadership of the village head.

The Village Law authorizes village governments to manage and develop their villages autonomously. It is hoped that with the empowerment and management program of village resources, the village community will be more prosperous. The pattern of village economic improvement can be carried out by the village government through Village-Owned Enterprises (BUMDes), managing the Village Income and Expenditure Budget (APBDes), and carrying out various infrastructure developments that can support an increase in the village economy so that the nation's development from the village can be realized.

Regarding the socialization of the implementation of Law Number 6 of 2014 concerning Villages, it is stated that the use and utilization of village areas as village resources is part of the determination of development areas following district/city spatial planning. Efforts that can be made to prevent the use of village funds from corruption include the following:

\section{a) MoU with the Community}

The MoU with the village community is very important to do considering that it can improve the harmonious order in carrying out the commitment to maximizing village funds, according to existing procedures. The MoU with the community will also lead to community participation in monitoring the village fund program.

\section{b) Village Fund Supervision Team}

With the existence of an independent supervisory team in opening up all spaces for the community without asking for representation in the supervision of village funds without limiting anyone to jointly supervise the use of village funds and always socialize with all existing development programs in the village to be committed to building the village together.

\section{c) Political Contract not to Corruption}


Political contracts are required for village apparatus managing village funds as part of their commitment not to abuse funds or power authority in the use of village funds. This political contract oath in writing (MoU \& MoA) by taking an oath and this MoU is believed to be effective in being able to create a sense of openness for fear of experiencing sanctions from God Almighty so that actions or efforts to prevent the use of village funds from corruption, village officials and village heads, as users of village funds, must be ready to be sworn in with a holy book according to their religion or make a legal agreement not to commit criminal acts of corruption in village funds.

\section{d) Firm Sanctions}

Enforcement of the law with sanctions can have implications for a deterrent consequence because it will have an impact on issues of self-esteem or bad morals that will be seen by the community and will become a conversation that damages personal and family self-esteem.

\subsection{Village Budget Vulnerability in the Pandemic Period and the 2020 Election}

Early in 2020, the world experienced a disaster with the outbreak of Covid-19 which finally plagued Indonesia in early March 2020, in the case of village funds during this pandemic, it is necessary to monitor the use of village funds in programs that have been established at village meetings, not to mention the potential threat of village funds to become fields. new criminal acts of corruption, especially some regions that will enter the political year (Pilkada) simultaneously which will take place in 270 regions consisting of 9 provinces, 24 districts, and 37 cities. High-cost political problems, which every year become a national polemic, are certainly prone to political corruption.

Village funds and ADD are two village budget items that are prone to be misused to win elections. The potential for the budget flowing into the village for the benefit of the Pilkada has been identified since the 2015 Pilkada concurrent, which was also the first year that village funds were disbursed from the APBN. The Center for Financial Transaction Analysis (PPATK) at that time even questioned the slow disbursement of village funds in several regional elections. PPATK suspects that this was deliberately done to bring village funds closer to the election schedule, namely December 2015.

It is believed that this mode of slowing down the disbursement of village funds is common. The aim is to gain the support of the village head or to politicize the use of village funds themselves. In the context of winning the election, the village head is considered a very strategic position. In addition to having great authority, the village head generally has close ties to the community and is an influential and trusted figure. The demand for high winning costs can also encourage regional head candidates to use public resources and funds for the benefit of winning the election.

It is not only regional heads who are advanced in the pilkada that have the potential to politicize village budget disbursements. Regional heads who side with certain candidates also have the potential to do this. It is known, as many as 115 districts that will hold the 2018 Pilkada have received an injection of APBN funds for 22,447 villages with a total budget of IDR 18.7 trillion. About 115 districts, there are at least 151 active regional heads (regents, deputy regents, and acting regents) running again. Not only district-level regional heads, but provincial-level regional heads also have the opportunity to politicize the village budget either directly or through the district head who is affiliated with it. 
Specifically, for village funds, in 2018, the government changed the time for disbursing village funds based on Permenkeu 225 / PMK.07 / 2017 concerning the second amendment to Permenkeu 50 / PMK.07 / 2017. Based on the Permenkeu, the disbursement of village funds which was previously carried out in two terms, namely 60 percent in March and 40 percent in August, becomes three terms, where the details are;

a. The first $20 \%$ term is the fastest in January and no later than the third week of June

b. The second term of $40 \%$ is the fastest in March and no later than the fourth week of June

c. The third term is $40 \%$ by July and the latest

d. Distribution from RKUD to RKD is made no later than 7 working days after village funds are received by RKUD

This change is based on the results of an evaluation of the use of village funds that have not been optimal for alleviating poverty among villagers. Therefore, this change was oriented towards the project on work so that the disbursement process that was brought forward to January was expected so that the funds could be absorbed and utilized by the villagers. In the context of simultaneous regional elections, this acceleration of village fund distribution can indeed reduce village funds that may be used as a political commodity, especially incumbents. However, some opportunities make village funds potentially politicized, including:

a. Regional heads who advance for regional elections only take leave, not resign. Indirectly, the regional head can still control the use of public resources and funds for the instrument of winning himself in the election. In the context of village funds, politicization can be carried out through the village empowerment agency (Bapermades) which promises to increase allocations or reduce allocations for villages that did not vote for it before it is stipulated in a Regent regulation. As is known, the disbursement or distribution of four of the seven village financial sources is below or at least involves the authority of the regional head (who generally moves back to become a candidate for regional head or supports one of the candidates). The four sources of finance are: APBN Allocation; Share of local taxes and levies; Village Fund Allocation (ADD) from regional balance funds; and Financial assistance from APBD.

b. The deadline for the distribution or disbursement of village funds. For example, the first term that is carried out at the earliest in January 2018 can be disbursed no later than the third week of June. So that the head area is possible to make an arrest when the village head refused affiliation.

c. There are personal or political ties between election candidates and village heads or village officials.

d. Poor internal and external village supervision

During a pandemic like today, where everything is extraordinary, the management of village funds is allocated to the handling of the Covid-19 pandemic, which requires accountability reporting that is carried out properly because village funds are public funds.

\subsection{Law Enforcement of Village Fund Corruption Crimes All the Time}

The development of normative law can never be separated from law enforcement which is an integral component of national development. The purpose of law enforcement is to create a sense of justice in society. Law enforcement efforts are very important as part of the pillar of Indonesia's statement as a rule of law. Therefore, anyone needs to enforce the law in Indonesia. Especially by law enforcers such as the police, prosecutors, courts and correctional institutions, and other state institutions. One of the things that are urgent to enforce the law is 
the criminal act of corruption, especially the corruption crime of village funds which ranks in the list of the highest corruption crimes in Indonesia.

Eradicating corruption crime needs to be optimized as the right answer in responding to the rampant corrupt behavior of government officials. If enforcement of the criminal act of corruption is successful, it will certainly have a wide positive impact on the life of the nation and state, especially the positive image of the people towards government management. This can occur because corruption is an act that destroys the constitutional system both from the side of governance (governance) and from the side of humanism. Corruption will also become a serious threat to the stability and security of the country which of course will impact the weakness of democratic institutions and values, ethical values, and justice and endanger sustainable development and upholding the rule of law. Concerning law enforcement in Indonesia, Lawrence Friedman has the following opinion:

a. The substance of the law is one of the factors that contribute to legal issues. The unclear substance of the law is not only easy for law violations to occur, but also provides ample opportunity for law enforcement officials to "frizz" according to their respective interests.

b. The legal structure is part of the structural system which determines whether or not the law can be implemented properly. It is based on Law Number 8 of 1981 concerning Criminal Procedure Law starting from the Police, Attorney General's Office, Courts and Criminal Implementing Bodies (Lapas). The authority of law enforcement agencies is guaranteed by law. So that in carrying out their duties and responsibilities apart from the influence of government power and other influences.

c. Legal culture, according to Lawrence Meir Friedman is the human attitude towards the law and the legal system - beliefs, values, thoughts, and hopes. Legal culture itself is an atmosphere of social thought and social forces that determine how the law is used, avoided, or abused. The legal culture is closely related to the legal awareness of the community, the higher the legal awareness of the community, the better the legal culture will be and the people's mindset changes towards the law itself.

In eradicating the criminal act of corruption, there are 2 (two) important things that must be carried out, the first is about positive law or laws and regulations that regulate corruption, and the second is about institutions that have criminal acts of corruption, both in the investigation and prosecution stages. and the trial. This understanding is deemed necessary because in both cases there will be specificities in regulating the criminal act of corruption itself and its Criminal Procedure Code. The criminal procedural law used in the handling of criminal acts of corruption, apart from being regulated in the Criminal Procedure Code, is also regulated in the law on the eradication of criminal acts of corruption, namely Law Number 31 of 1999 as amended by Law Number 20 of 2001. Meanwhile, if you look at the institutional aspects, namely institutions for investigation, prosecution, and courts that adjudicate other than those judging other than those stipulated in various scattered laws and regulations such as Law Number 10 of 2015 concerning the Corruption Eradication Commission and Law Number 46 of 2009 concerning Corruption Criminal Court.

Institutions that have the authority to handle corruption, both in the investigation, prosecution, and trial stages have specifics, namely: there are three institutions authorized to investigate criminal acts of corruption, namely the police, the prosecutor's office, and the Corruption Eradication Commission. Regarding investigations, it is the authority of the Police Investigator, so that the handling procedure is the same as the procedure for handling criminal acts in general, by submitting the results of the investigation file to the Public Prosecutor at the Prosecutor's Office by their jurisdiction. If the prosecutor believes that the case file has met 
the formal and material requirements, the case file can be submitted to the corruption court (Tipikor). Regarding the investigation of corruption crimes carried out by KPK investigators, the KPK investigators will submit the case files resulting from the investigation to the Prosecutors at the KPK and then delegate them to the corruption criminal court.

The institution authorized to prosecute criminal acts of corruption is the Public Prosecutor (JPU) with the following mechanism: 1) case files resulting from investigations by KPK investigators, then prosecution is carried out by the prosecutor assigned to the KPK; 2) Regarding case files resulting from police investigators and prosecutors' investigators, prosecutors who are at the AGO will continue to carry out the prosecution. Thus, apart from the investigations carried out by the KPK, the prosecution is still carried out by the Public Prosecutor from the Prosecutor's Office, while the prosecution results from the KPK investigators are carried out by the Public Prosecutor, meaning that even though in the KPK the prosecution must still be carried out by the Prosecutor.

Meanwhile, the institution that has the authority to try corruption cases is the Corruption Crime Court (Tipikor) as stated in Law Number 46 of 2009 concerning the Corruption Crime Court, that trials of corruption cases must be tried in a special court for Corruption Crime under the regional law.

\section{Conclussions and Suggestion}

\subsection{Conclussions}

The increase in corruption cases in the village sector is a negative note and a bad precedent for the Indonesian government, especially in the enforcement of the criminal law of corruption, which has been an aspect of the central government fighting. It cannot be separated from the discussion on evaluating central government policies related to villages.

Corruption and misuse of village budgets will certainly harm the ideals of accelerating village development as well as improving the welfare of village communities. In the 5 (five) years after the implementation of the policy to support village funds from the APBN, it seems as if it creates new problems, such as the poverty rate which should decrease, but the opposite happens. Data from the Central Statistics Agency (BPS) states that the poverty rate increased from 30.07 million in September 2018 to 32.77 million people in March 2019. Therefore, it is necessary to prevent the misuse of village budgets. What the government needs to do primarily is to ensure access to information and community involvement in village development. To make this happen, the village government certainly has to open information and of course, the village community must also be actively involved, committed, aware of the development of their village, and build each other's knowledge of the importance of managing programs funded by village funds to run in a transparent and accountable manner. Furthermore, regarding the implementation of the Pilkada, the authors urge that:

a. The need for a professional attitude and utilizing the village fund budget by the Regional Heads, for the village head it is hoped that it will not become a means of winning the election.

b. Collaboration between the Ministry of Village's PDT and the Ministry of Home Affairs to remind village heads not to be affiliated with certain regional head candidates, if necessary, make a report center contact if forced to violate election rules.

c. Ministries with an interest in disbursing village funds need to work with PPATK to supervise districts that are slow to distribute village funds and report them. 
d. The government also needs to collaborate with local village communities to supervise village programs funded from village funds, if there are odd things, they can report to the government through a digital portal.

Other conclusions from discussions related to the legal policy of village fund corruption include (1) an MoU with the community intending to commit to building the village simultaneously with the village fund supervision team; (2) establishing an independent supervisory team to supervise the village fund management program; (3) The village head and village officials are ready to undertake a political contract and an oath not to corrupt village funds; (4) strict sanctions for perpetrators of village fund corruption with the purpose of not providing a deterrent effect on other village officials. It is hoped that community participation will involve themselves in the supervision of the planning, implementation, and evaluation of the use of village funds, so that village development can be realized according to the wishes of the villagers.

Actions taken by law enforcers are under the procedures in the Criminal Procedure Code (KKUHAP) and the special provisions stipulated in the Corruption Crime Law, namely starting from investigations, examinations, prosecutions, and executions. Obstacles that often occur in law enforcement of corruption in village funds include differences in the perception of law enforcers in calculating state financial losses, escape of suspects, difficulty in presenting witnesses due to low legal knowledge of villagers, convicts do not have assets to pay compensation for state financial losses. Efforts that must be taken by law enforcers to enforce the law on corruption are carrying out case titles, conducting DPOs (search for person list) against suspects, asset tracking.

\subsection{Suggestion}

Based on these conclusions, the suggestions that can be used as policy recommendations are as follows:

1. In the future, law enforcement agencies in the law enforcement of village funds corruption are not only repressive but also need to consider preventive and pre-emptive measures.

2. For the Village Chief in each village to be more careful in using village funds so that village fund corruption does not occur, he can also submit consultation to the Village Community Empowerment Service if he does not know the technical instructions for managing village funds.

\section{Acknowledgment}

This paper is a research report entitled "The Legal Policy for Village Fund Corruption, Towards Effectiveness of Village Fund Management and Building Indonesia from the Village". Therefore, the author would like to thank the lecturers at the Borobudur University Jakarta Doctoral Program, especially the promoters of the author's dissertation. And also enlarge the appreciation to the families of parents, wives, and beloved children who have volunteered the author's time to take education and so for colleagues at the Police Headquarters. 


\section{References}

[1] Adhayanto, Oksep, et al. Aspek Kriminologi Terhadap Tindak Pidana Korupsi Dana Desa (Studi Kasus Putusan Nomor: 32/PID. SUS-TPK/2017/PN. TPG). Student Online Journal (SOJ) UMRAH-Ilmu Sosial dan Ilmu Politik, 2020.

[2] Arfiansyah, Mufti Arief. Pengaruh Sistem Keuangan Desa dan Sistem Pengendalian Intern Pemerintah Terhadap Akuntabilitas Pengelolaan Dana Desa. JIFA (Journal of Islamic Finance and Accounting), 2020.

[3] Bunga, Marten; Aswari, Aan; Djanggih, Hardianto. Konsepsi Penyelamatan Dana Desa Dari Perbuatan Korupsi. Halu Oleo Law Review, 2018.

[4] Daniati, Sri. Tingkat Partisipasi Masyarakat pada Perencanaan Penggunaan Dana Desa Dalam Rangka Pengentasan Kemiskinan di Desa Kesimantengah. Jurnal Ilmiah Administrasi Publik, 2019.

[5] Friedman, Lawrence M. A history of American law. Simon and Schuster, 2005.

[6] Habibi, Fikri; Nugroho, Arif. Penerapan Dimensi Akuntabilitas publik dalam pencegahan korupsi dana desa di Kabupaten Pandeglang. Jurnal Ilmu Administrasi: Media Pengembangan Ilmu dan Praktek Administrasi, 2018.

[7] ICW, Indonesia Corruption Watch. Outlook Dana Desa 2018 Potensi Penyalahgunaan Anggaran Desa di Tahun Politik. 2018.

[8] Kadir, Yusrianto; MOONTI, Roy Marthen. Pencegahan Korupsi Dalam Pengelolaan Dana Desa. Jurnal IUS Kajian Hukum dan Keadilan, 2018, 6.3: 430-442.

[9] Kristiana, Yudi, Teknik Penyidikan dan Pemberantasan Tindak Pidana Korupsi (Yogyakarta: Thafa Media, 2018)

[10] Makhmudah, Maratul. Pencegahan Terhadap Tindak Pidana Korupsi Pemerintah Desa: Kajian Politik Kebijakan dan Hukum Pengelolaan Sumber Daya Alam Desa, Fakultas Hukum Universitas Islam Malang, Fakultas Hukum Universitas Brawijaya Malang”, Yustisia 9 Mei- 5 Agustus 2016.

[11] Mahmud, Mohammad Ginanjar; Dahlan Ali, Eksekusi Uang Pengganti Terhadap Terpidana dalam Tindak Pidana Korupso Oleh Kejaksaan Tinggi Aceh, Jurnal Kanun Ilmu Hukum, 18.2 (2016).

[12] Manihuruk, Tri Novitasari. Penegakan Hukum Tindak Pidana Korupsi Dana Desa Di Kabupaten Kampar. Jurnal Gagasan Hukum, 2019.

[13] Marzuki, Peter Mahmud, "Penelitian Hukum", Jakarta:Kencana, (2011).

[14] M. D. Matutu, A. Latief \& H. Mustamin, Mandat, Delegasi, Attribusi dan Implementasinya di Indonesia. Yogyakarta: UII Press. 2004

[15] Permatasari, Elfiras; Adjie, Habib; Djanggih, Hardianto; Perlindungan Hukum Kepemilikan Tanah Absentee yang diperoleh akibat pewarisan. Varia Justicia, Vo. 14, No. 1, 2018

[16] Rahman, Fathur, "Korupsi di Tingkat Desa" Jurnal Governance, 2.1 (2011): 16.

[17] Rifai, Eddy, "Dana Desa dan Pemberantasan Tindak Pidana Korupsi", Makalah dalam Diskusi Membedah Kedudukan MoU Polri dan Menakar Urgensi Pembentukan Densus Tipikor, APEDI, Bandar Lampung, 11 November 2017.

[18] Riyanto, Teguh. Akuntabilitas Finansial Dalam Pengelolaan Alokasi Dana Desa (Add) di Kantor Desa Perangat Selatan Kecamatan Marangkayu Kabupaten Kutai Kartanegara. Ejournal Administrasi Negara, 2015.

[19] Rustiarini, Ni Wayan; DENPASAR, U. M. Good Governance dalam Pengelolaan Dana Desa. Simposium Nasional Akuntansi, 2016.

[20] Sari, Nani Widya, "Kewenangan Kejaksaan dalam Penegakan Hukum Tindak Pidana 
Korupsi dihubungkan dengan Undang-Undang Nomor 16 Tahun 2004 Tentang Kejaksaan Republik Indonesia", Jurnal Surya Kencana Dua: Dinamika Masalah Hukum dan Keadilan, 4.2 (2017).

[21] Suganda, Delfi. Fungsi Strategis Tuha Peut Dalam Melakukan Pengawasan Dan Pencegahan Korupsi Dana Gampong. Al-Idarah: Jurnal Manajemen dan Administrasi Islam, 2018.

[22] Surya, Achmad. Problematika Penyidik dalam Penetapan Tersangka Tindak Pidana Korupsi Dana Desa di Kabupaten Aceh Tengah. RESAM Jurnal Hukum, 2018.

[23] Walesa Putra, I.; Widhiyaastuti, I. Gusti Agung Ayu Dike; PUTRA, I. Putu Rasmadi Arsha. Peran Serta Masyarakat dalam Pencegahan Tindak Pidana Korupsi Pengelolaan Keuangan Dana Desa, Studi Di Desa Cau Belayu, Kecamatan Marga, Kabupaten Tabanan, Propinsi Bali. Acta Comitas, 2018.

[24] Waluyo, Bambang, Optimalisasi Pemberantasan Korupsi di Indonesia, Jurnal Yuridis, Vol. 1, No. 2 Desember 2014

[25] Wibisono, Nurharibnu. Mengungkap fenomena pengawasan publik terhadap dana desa di Kabupaten Madiun. Jurnal AKSI (Akuntansi Dan Sistem Informasi), 2017.

[26] Wiyanto, Siko Dian Sigit. Agar dana desa terkawal. Kementrian Keuangan, 2014.

[27] Undang-Undang No. 6 Tahun 2014 Tentang Desa. Republik Indonesia, 2014.

[28] Peraturan Menteri Desa, Pembangunan Daerah Tertinggal, dan Transmigrasi Republik Indonesia Nomor 6 Tahun 2020 Tentang Perubahan Atas Peraturan Menteri Desa, Pembangunan Tertinggal, dan Transmigrasi Nomor 11 Tahun 2019 Tentang Prioritas Penggunaan Dana Desa Tahun 2020

[29] https://nasional.kompas.com/read/2020/02/18/19084421/catatan-icw-kasus-korupsidana-desa-terbanyak-muncul-pada-2019 diakses 6 Agustus 2020 